\title{
Perfume of Musk in the Narrative of "One Thousand and One Night" (Alf Lailah Wa Lailah)
}

\author{
Dr. Salih Ali Al-Shora ${ }^{1}$ \\ ${ }^{1}$ Associate Professor, the World Islamic Science \& Education University, Jordan \\ Correspondence: Dr. Salih Ali Al-Shora, Associate Professor, The World Islamic Science \& Education \\ University, Jordan. E-mail: alshora_salih1971@yahoo.com
}

Received: November 14, 2019

Accepted: December 5, 2019 Online Published: December 11, 2019

doi:10.5539/mas.v14n1p7

URL: https://doi.org/10.5539/mas.v14n1p7

\begin{abstract}
This study aims at discussing in usages of Musk in fables of the Narrative of "One Thousand and One Night" (Alf Lailah Wa Lailah), and since most of fables provided in the Narrative are performed on imagination the perfumes were heading their vocabulary, for their connection with the psychological factors that form the movement of human beings. And employing musk had been strongly present in that narrative, and the narrative asserted on the people, who were employing musk were from the rich and luxurious class in the community, because of its high price, the matter that enhanced, in turn, at the author of the narrative to go on dyeing his fables related with the first class with the scent of musk to bestow upon them something of reality. This is in addition to looking at some usages of musk that were connected with myths and legends for the musk to be the ambassador between reality and imagination.
\end{abstract}

Keywords: narrative of "One Thousand and One Night", perfumes, musk

\section{Introduction}

Fables of (One Thousand and One Night" (Alf Lailah Wa Lailah) strech too far away to cover civilizations and cities established across history, because they are fables collected in them variant cultures, Arabic, Persian, Indian and Greek. The civilized inter- culturealization, among nations had a great role in making this narrative a distinguished work, branching cognitions and the intellectual trends, And since the perfume accompanied the travel of man since the whole creatures. It cannot be specified when perfumes started to write their history except if we specified when man wrote accurate beginning of the history of his relationship with nature and its constituents, so the history of perfumes is directly connected with the history of human beings and its fables. And accompanied its usage with performing temples and taking the gods connected with ancient beliefs, and perhaps the first usage of perfumes was interweaving with the religious rituals. And spread indications in fables of "One Thousand and One Night" are provided to using perfumes with all their forms and in numerous occasions. This study works to observe what is related with musk of psychological and sociological usages. In addition to the abundant effectors to which the narrative prepared the mention of perfumes in general and musk in particular, such as cases of marriage, and celebrations, lovers meetings and else. The study also discusses the psychological factor that formulated a relationship between wealth and musk, and this affection in those fables can be coming from the real understanding, which was chronicled by historians about the life of lavish expenditure in those places. The book of "One Thousand and One Night" is a group of stories and popular fables that tackled products of numerous cultures, Arabic, Persian, Egyptian, Indian and else. It had included numerous human stories connected with the man feelings from love, sophism, asceticism, and needs of the soul. Beside what are included of many subjects ignored by numerous sources. The musk was famous to be brought to Arab countries from China, country of Tibetans India. And the musk that is brought from Tibet country is considered the best of these types, that is because of the pastures of the deer in that country the better than else of other countries. And within this climate the trade of fragrant perfumes and their industry. And entered in the cultural inheritance of the community movements, and so came accompanying it in happiness and sadness, though the methodology of the study is the historical description. The study will tackle: the definition of Musk, places of its existence, its economic significance, and group use it, its psychological usages, and women's usage of it, and then results deduced by the study. 


\section{Problem of Study}

The problematic to which the study sought conceals in answering two primary questions, they are:

1- With what Musk represented of a valuable perfume matter in the narrative of "one thousand and one Night" what is the extent of its usage compared with other perfumes in the Narrative.

2- Did usage of Musk confine to one group of people starts from one social category.

Objective of Study: The study aims at shedding light on the perfume, Musk wherever it was provided in the Narrative, and discussing the perceptual usages, and it attempts to rise the cause of its choice rather than else, and this in turn works to disclose the secret sides of the human relations that was formed in persons of the narrative.

Previous Studies: among the literary and historical narratives, that researchers entrusted their concern, is the narrative of "one Thousand Night" The previous studies concentrated on the movement incidents, and the relationship of man with man, or his relationship with the place. But the narrative remained a virgin domain for researchers, where the previous studies ignored the perceptual moral sides, connected with perfumes, especially Musk.

\section{Musk Definition}

Musk is a type of perfume taken from a sort of gazelle or deer (Al-Mu'jam Al-Waseet, 200) Medium Dictionary. Musk is Persian (Muskh): it is a perfume taken from an animal source (AlMu'jam Al-Waseet) Medium Dictionary, 200, also it was provided that Musk is a matter extracted and obtained from the belly of the gazelle. And because of its importance Musk was provided in the Holy Qura'n, in an evidence of its importance and its fragrant scent. The Al-Mighty God said "Whose seal is musk- For this let (all) those strive who strive for bliss:(Holy Qura'n, Defrauding, verse 26) "Al-Mutaffifin" also the Prophetic Sunnah asserted this matter through the Prophet's (peace be upon him) Hadith, he said: "Certainly the smell of the fasting Moslem's mouth is more so beloved at Allah (God) than the scent of musk" (Prophetic Hadith). The musk has abundant sorts and different races, and the bests of them is Tibetan, brought from Tibet country, and the Qusari Musk, brought from Qusar country between India and China Land it is with good color, but it is with weak smell. (Al-Ya'coubi, 292H.).

But what was provided in the Narrative of "One Thousand and One Night" of what concerns the definition of musk, it had been provided in a fable indicates to that: "Be informed my brother that Allah (God) the Al-Mighty expelled Adam from paradise, together with four leafs concealed himself and fell in earth, one of them was eaten by worms and became of it silk, the second was eaten by gazelles and became of it the musk, the third was eaten by the bees and of it became the honey, and the fourth one fell in India and became of it pepper and spice. "(One Thousand and One Night, Night 542, 1948). Also came in the narrative, that the musk is a matter with black color and a fragrant scent inspite of its dark color". "And except for the blackness of musk and ambergris, the perfume will never be carried to kings or be mentioned, and how plenty of boasts by blackness are done", and how is it good the saying of the poet: "Did not you see the musk its prestige is glorified, and the whiteness of limestone is being carried for one Dirham, and about the eye's whiteness the lad makes it ugly, and the eye's blackness shoots with arrows". (One Thousand and One Night, Lailah 76, 1984).

\subsection{Places of Availability of Musk}

Sources in which musk is available variated due to fables of the narrative of "One Thousand and One Night", it may be obtained from more than one spot in this globe it had been provided at a moment of passionate love that the most important place of its availability was Iraq. This is what was brought by the text saying Oh flagrance of musk and perfumes from the land of Babble, with the right of my passion and fondness I pray perform my letters. "(One Thousand and One Night, Night 946, 1984). Also China is considered from the main sources of Gazelle Musk, it was provided in Yaqut Al-Hamawi's Book. And some tribes of China had statues from horns of musk gazelles". (Al-Hamawi, 1995) and was also brought from India "Also musk is brought from other zones and India, from where musk was exported to Bahrain country" (Al-Hamawi, 1995). And from Tibet country as well. "Musk is also brought from Tibet country to different Islamic countries" (Al-Hamawi, 1995).

"And Yagout Al-Hamawi mentions that musk came from Al-Wakhab zone in the country of horses, the Turks country that was famous for musk, bondmen, and precious metals like gold and silver". (Al-Hamawi, 1995). In this, is an evidence that the gazelle from which musk is extracted lives in a special environment, and it is clear from the previous narrations that the most appropriate circumstances of this type exists in China and the surroundings. 


\subsection{The Economic Significance of Musk}

Musk was a demand for some categories of the community, therefore this matter had been a source of wealth for numerous merchants, it had been provided in the narrative "she said: I have been informed, you happy king, that the merchant had left a great amount of money for them and from the total of that a hundred burden of silk, silk garment, and braggarts of musk" (One Thousand and One Night, Night 52, 1984). It was also provided what guides to employ musk in places of richness "so she said to him I want four braggarts of musk with fragrant scent, and four expensive leaves in addition to four pounds of ambergris, (One Thousand and One Night, Night 791, 1984). This trade of musk had been widespread, so there found special markets for it, where it was the most important good in the market of perfumers, from which smells of perfumes smell fragrantly with all types. It had been conditioned in the one who deals with this matter to have experience in making the perfumes, their types and prices, so it was considered a craft not any person enjoys. Therefore the narrative indicated to such matter indirectly, when came in it: "They left them and went to the market of perfumers, suddenly their shops were full of types of perfumes, braggarts of musk, ambergris, aloes (wood), and camphor" (One Thousand and One Night, Night 791, 1984).

\subsection{Categories that Use Musk}

Since musk is considered a precious matter with high value not anyone can easily obtain it, its usage had been confined to categories of luxurious people and upper class like: Caliphs' women. It had been provided in Yagout Al-Hamawi's Book: "Even Al-Rashid when used to get out to the retinue the smell of his clothes spread the musk scent and incense" (Al-Hamawi, 1995). This is what abundant stories provided in the sources, assert like: and the Caliph Al-Mahdi gave Al-Mughireh Bin Habib Bin Thabit Bin Abdullah Bin Al-Zubair Thirty Thousand dinars. "And gave him musk, ambergris, and magnificent clothes from his particular clothes". (Al-Baghdadi, 463H.). And because of the importance and value of musk Kaphor Al-Ikhshidi was nick-named Abu musk (father of musk) (Al-Tanokhi, 1995) and as Al-Tanokhi mentions "That he expended to Al-Muqtader kitchen monthly, three hundred dinars as price of musk added to food" (Al-Tonokhi, 1995), thereupon the writer of the narrative "One Thousand and One Night" perceived the significance of musk and categories that use it, therefore he did not provide the stories that mix between musk and common people.

\section{Usages of Musk at Women}

The relationship between of perfumes in general and Musk in particular and women arguments, the women doesn't stop using musk, but because of its high price it was confined to rich women. (Almousawi, 2016)

When the narrative of (One Thousand and One Night) treated usages of musk by women, it desired to connect it with the luxurious of them, the news came talking about women of places and identical from women of the community, and had observed here from such narrations of luxurious women who were notified on men, so said one of the poets who met one of the palace women: "I stood up from my place and took the hand kerchief with me then opened it so it smelled with fragrant musk, so I have got a great delight till I became as if I were in Paradise"... (One Thousand and One Night, Night 570, 1984). And another story talks about one of the Princes who awoke from his sleep and found one of them (women) beside him: "So she moved beside him and found something standing erect beside him more righteous than musk and its body more tractable than butter so he wondered....",...(One Thousand and One Night, Night 139, 1984). And another story with the same meaning "And I was the more I Joined her to my chest I smell from her the smell of musk and perfume, and I do not think except I was in paradise or I am in a paradise dream". (Al-Sama'ani, 1962) and this urges us to say that the woman abundantly used this matter not for perfuming itself at the extent it has of moral value in attracting the attention of men who are attracted by those women.( Tannous, 2010)

\section{Psychological Usages of Musk}

It was deduced on using musk in the narrative of "One Thousand and One Night" on this type of perfumes in abundant and numerous connected with aspirations of people souls and their beliefs performed on the period of time and place, and it had been represented in the various types of usages to musk in gifts and women's adornment, and the relationship of man with the woman. It was provided that musk was the original companion of luxurious men's usages, especially on Friday, according to the necessity of the man's getting out to the Friday prayer with his complete appearance and perfuming, and what indicates to this matter in the forty two night that "People are looking at him while they are strolling to the Friday prayer, of them who glances him.....suddenly a woman coming to Friday prayer with her great beauty and spreads from her the smell of musk",...(One Thousand and One Night, Night, 42, 1984). 
Also musk usage entered in making food of the luxurious people, especially sweets, it came in the narrative "The man shouted to his followers to forward the sweets, then the house owner said to my brother: eat from this type it is good and eat from these velvets, and take this velvet before its sweet comes down my brother said to him: never to be deprived of you sir, and my brother continued asking him about abundance of musk in the velvets he said to him: this is my habit always at home, they make in every velvet a weight of musk and half weight from ambergris, this all is done and my brother moves his head and mouth, and plays with his tongue between both corners of his mouth as if he enjoyed eating sweets",...(One Thousand and One Night, Night 43, 1984). We view that the strength of luxury of the luxurious class, they mixed up musk with provender's of poultry, till the taste of the bird meat mixed up with musk smell. So it came on the tongue of one of luxurious heroes in the narrative "This is not a meat of a bird only, I provide it with grains of musk and its meat remains like musk",....(One Thousand and One Night, Night 654, 1984). And thing had been provided, guides to the Abbasside Caliph, Al-Muqtader's extravagance as Al-Tunokhi mentions, for using perfumes in plants fertilizer and this is what the narrative asserted "That musk was mixed up with fertilizer to aid plants on growth, and protect them from epidemics" (Al-Tunokhi, 1995).

Also it was provided in the narrative originally performed on the fable and penetrating the depths of the human soul that people communicated with the other world through complicated rituals mixed-up with the smell of musk, that attracts strongly demons and devils, so they burnt musk to prepare the place to receive these entities, the following was provided in the narrative: "Take a brazier of fire and throw something of musk to give a smoke attracts the devils, if you have done that so they are present at your hands all, no one of them is absent and they obey your command.. Anything you did command they do it, so stand and take action of that..",... (One Thousand and One Night, Night 350, 1984) and also provided "Then wherever we burn the eagle with musk soon devils had come from everywhere, and said: here I am! At your service! Whatever you want to do and I commanded them to transport all what is there in the city from copper and brass, money, metals and jewels to my house in Basra and they did that",....(One Thousand and One Night, Night 351, 1984). And it seems that the goal from using smells of musk at the author of the narrative in this place, performed on connecting its delicious smell and its supernatural ability of dominating the invisible entities, to message the reader with the extent of musk strength and its influences that surpass the perceptions of human beings.

Musk entered King's letters to their parallels of rulers to easy convince them with the content of their letters and its example "The queen is the life of souls wrapped that paper in a label of expensive silk moistened with musk and laid with it the braids of her hair that cost money with their price then wrapped them and gave them to the servant and commanded him to transport them to the glorified King,....(One Thousand and One Night, Night $235,1984)$ musk was the messenger of love and happiness at palaces, so came "And I want to marry her and let judges write a title deed with her enfolding, then write my marriage contract on her and throw musk on heads of the present people abundant gold, so lads and servants started picking them up..., ,.....(One Thousand and One Night, Night 76, 1984).

Also plenty of stories were provided in the narrative that address the human soul and let it obey, to accept what was not familiar to it before with the influences of musk, and so came "When entered into that door he saw a place spread-out with silk garment and its walls, on them silk curtains numbered with gold and in it fumigators of aloes (wood), ambergris, and musk with fragrant scent spread with silk garment and saw a bed in the front, so he sat on it and was absent with the woman and was unaware of what had been written in the invisible world",... (One Thousand and One Night, Night 282, 1984). And from the other psychological usages of musk, that guide to its strong presence in dining tables of the rich people, it is being mixed up with drinks by grinding or crushing them melting it by those drinks to give them the delicious taste and fragrant scent, where the Caliphs and Princes were introduced. It was provided in the narrative: "That the pretty good-looking's took the cup and perfumed it with flower - water and ground musk and came to Masroor and received it",...(One Thousand and One Night, Night 799, 1984).

The narrative did not neglect the high value of musk where it was considered an acquirement of the war acquirements as provided "And at war of Al-Muwafaq and Yacoub Bin Laith Al-Safar, Al-Muwafaq gained money and sacks of musk". (Ibn ElAtheer, 1997) also provided that when Karaman King announced his disobedience against Alb Arislan, he sent to Alb Arislan afterwards to show obedience, and sent gifts and donations of great value including a cup of turquoise, containing two sorts of musk,....(One Thousand and One Night, Night 314, 1984). Usages of musk were not confined to the previous purposes, also it played a big role in influencing receivers, it was the first medicine in cupboards of doctors MD, where it was employed in awakening the unconscious person for its sharp smell, it came in the narrative "The they spread flower water mixed up with musk and civet on his face, so he awoke and looked at the lady, Shamsah and said: Praise be to 
Allah, Lord of the World, who empowered me attain my goal and extinguished my inflaming, till no inflaming remained at my heart,.... (One Thousand and One Night, Night 520, 1984).

\section{Conclusion}

The author of the narrative "One Thousand and One Night" desired to connect musk with the human psychological factors, so he showed, in his fables, the great deal of his influences in breaking barriers between the man and the woman. And the subject of perfumes had occupied, especially musk, an important part from fables of the narrative, so it was a messenger of love among lovers, and a commander at palaces of great people, it is the address of gorgeous gifts among Kings, and it is the highway to those who wanted wealth, and the means to those who wanted individuality. Also it is the companion of the religious rituals and occasions and the formal ones with its sentimentally perceived attribute, and it is the thin thread that connects between humans and jinn. This is in addition to its touched usages in food and drink, and the formal ceremonies, therefore a special budget was specialized for it at palaces of Caliphs and wealthy people.

\section{References}

Al-Khatib \& Al-Baghdadi (1980). Bahgdad History, Edited by Bashhar Ma'roof, Beirut, Dar Al-Gharb Al-Ismail (The Islamic West House), 16 Parts, 256-344.

Almousawi. Mohsen (2016). The popular Memory for Communities of "one Thousand and one Night", Rabat, Morocco, the Arab Cultural Center, 210-370.

Al-Mu'jam \& Al-Waseet (2000). (The Medium Dictionary) Musk Matter, Beirut, Dar Ihya' Al-Turath Al-Arabi (Arab Inheritance Animation House).

Al-Sama'ni \& Abdel Kareem (1962). Al-Ansab, Edited by Abdel Rahman Bin Yahya Al-Yamani, Haider Abad, Council of the Ottoman Department of Education, 77- 155.

Al-Tunokhi (1995). Lecture Show and Discussion News, 8 Parts, Edited by A'bboud Al-Shaliji, Beirut, Dar Sader, $2^{\text {nd }}$ edition, 294-311.

Al-Yacoubi, Al-Buldan, Beirut, Dar Al-Kutob Al-I'lmeyah \& Diene loco (Scientific Books House), 195-311.

Ibn ElAtheer, (1997). The Complete in History (Al-Kamel Fi Al-Tarikh), 10 Parts, edited by Omar Bin Abdel Salam Tadmori, Beirut, Dar elKitab Al-Arabi (Al-Arabi Book house), 212.

One Thousand and One Night, four parts, (1984) edited by Abdel Saheb Al-I'qabi, Al-Nahdah Bookshop, Baghdad.

Tannous, Jan (2010). Woman in one Thousand and one Night, Beirut, Dar Almanhal, 51-112.

The Holy Qura'n. \& Sahih Muslim.

Yaqout Al-Hamawi (1993). (Dictionary of Countries), Beirut, Dar Sader, $2^{\text {nd }}$ Edition, 7 parts, Mu'jam Al-Odaba' (Men of Letters Dictionary), 7 Parts, Edited by Hassan A'yyash, Beirut, Dar Al-Gharb Al-Islami (Islamic West House), 322-464.

\section{Copyrights}

Copyright for this article is retained by the author(s), with first publication rights granted to the journal.

This is an open-access article distributed under the terms and conditions of the Creative Commons Attribution license (http://creativecommons.org/licenses/by/3.0/). 